Article

\title{
Gender in a Box? The Paradoxes of Recognition beyond the Gender Binary
}

\author{
Sofia Aboim \\ Instituto de Ciências Sociais, Universidade de Lisboa, 1600-189 Lisbon, Portugal; E-Mail: sofia.aboim@ics.ulisboa.pt
}

Submitted: 27 January 2020 | Accepted: 10 July 2020 | Published: 18 September 2020

\begin{abstract}
The growing visibility of trans and gender-nonconforming individuals paved the way for a novel politics of transgender recognition in the legal sphere and state-governed public policies. Considering that the possibilities for registering multiple genders beyond male or female are taking effect in several countries, this article examines recent developments and claims that recognition is complicit with misrecognition for two main reasons. Firstly, because models of recognition tend to equalize all the interactions and all the fields of social life. Drawing on Axel Honneth's notion of spheres of recognition, I argue that inasmuch as different forms of recognition (legal, moral, affective) are governed by different norms and gender regimes, the dynamics of recognition produce misrecognition. Secondly, because legal and institutional recognition tends to reify individual identity. Drawing on Nancy Fraser's critique of the identity model of recognition, I contend that the identity recognition model tends to impose a norm rather than recognizing diversity. Therefore, gender identity categories can-through a process of reification-block the entitlement to affirm one's self-determined gender identity. The paradoxical dynamics of recognition are empirically illustrated through an analysis of third-gender markers and their effects upon the lives and narratives of trans and gender-nonconforming individuals. By examining the case of Nepal in comparative perspective with other developments in Asia and South America, it is demonstrated that the identity model of recognition is complicit with feelings and practices of misrecognition.
\end{abstract}

\section{Keywords}

gender; identity politics; misrecognition; Nepal; non-binary genders; third-gender markers; trans

\section{Issue}

This article is part of the issue "Trans* Politics: Current Challenges and Contestations" edited by Mieke Verloo (Radboud University, The Netherlands) and Anna van der Vleuten (Radboud University, The Netherlands).

(C) 2020 by the author; licensee Cogitatio (Lisbon, Portugal). This article is licensed under a Creative Commons Attribution 4.0 International License (CC BY).

\section{Introduction}

In recent years, gender identity gained centre-stage as a growing number of individuals claimed the right to a gender identity outside the binary model that opposes male and female. However, while the emergent visibility of trans, gender-nonconforming, gender nonbinary or intersex people paved the way for reframing gender citizenship afar from the medicalized model of transsexuality first established by endocrinologist Harry Benjamin in the 1950s (Baisely, 2016; Dunne, 2017), the political inroad to transgender recognition remains filled with controversy (Powell, Shapiro, \& Stein, 2016; Sky, 2018). Reconciling freedom for self-determining one's own gender with state-sponsored governance of official gender identities beyond masculine or feminine has been an arduous struggle. If the state often fails to recognize gender diversity and renders people's lives 'administratively impossible' (borrowing Dean Spade's expression [Spade, 2015, p. 12]), within the transgender and non-binary activist movements, the consensus remains absent. Trans activism is fractured (Halberstam, 2018, p. 12). For some, gender should be simply abolished and legal categories rendered unnecessary (Davis, 2017). For others, 'transgendering recognition' is a central goal of transgender and gender-nonconforming claims for rights (Juang, 2013). Ideally, as Judith Butler argued (Butler \& Williams, 2014, p. 1), "one should be free to determine the course of one's gendered life," even if as, as Butler also notes, while "some want to be genderfree...others want to be free really to be a gender that is crucial to who they are." However, while transforming 
gender classification systems is key, legal and administrative strategies to move beyond binary categories of gender and regulating gender difference are multifarious (Clarke, 2019).

The recent wave of legalization of third-gender or no-gender markers by some states across the globe generated upheaval. Whereas ideals of a postgendered or genderless society encountered contestation (Sky, 2018), the state-controlled multiplication of official gender markers designed to accommodate diverse gender identifications gained pace. Indeed, the legal recognition of non-binary gender markers by the state (whether $\mathrm{X}$ in Australia or Denmark, Diverse in Germany, Others in India or Nepal) is often interpreted as a victory for the trans rights movement (Young, 2016). Notwithstanding, critical scholarship has, since long, criticized state categorizations and the ways official markers serve to govern difference in ways that perpetuate unjustness (e.g., Foucault, 1988). After all, although representing a revolutionary advance, the gender neutrality of a $\mathrm{X}$ marker can be more apparent than real. After all, neutral gender markers lend themselves to categorical interpretations that 'third-gender' and 'third-sex' (Dembroff \& Wodak, 2018, p. 386) trans and gender non-binary individuals as pertaining to the supplementary category of a ternary gender system of classification.

Problems with the articulation of gender identity laws, gender-neutral classifications and, specifically, legal third-gender markers have been particularly highlighted (Bochenek \& Knight, 2012; Knight, Flores, \& Nezhad, 2015). After all, present-day legal forms of recognition might also foster reification and marginalization (Markard, 2018). However, although current state responses are most often frowned upon and third-gender markers deemed complicit with binary norms of gender (e.g., Nisar, 2018), legal restrictions enforced by binary categorization schemes continue to be denounced as harmful (Davis, 2017; Monro, 2005; Salamon, 2010; Spade, 2008).

If current strategies for transgender recognition generate misrecognition and perpetuate discrimination (Fine, Torrea, Frost, \& Cabana, 2018), the lack of recognition denies the social existence of the person and compromises any positive effects of increased visibility (Juang, 2013). Therefore, state-endorsed recognition of gender diversity is still limited and potentially misleading. While solutions for recognizing gender-nonconforming individuals remain under heated debate, reconciling categorization (through the addition of third or seemingly neutral gender markers) with the entitlement to publicly display and affirm one's own self-defined gender identity is a difficult endeavour. Hence, even if we admit that legal categories are not suited to accommodate people's subjective identification, the rift between claims for recognition and pleas for the abolition of gender markers suggests that we need to further reflect on the concept of recognition. While recognition is simultaneously a normative regulative ideal and a descriptive tool (McNay, 2008, p. 2), my focus remains mainly descriptive as I seek to understand the paradoxes of recognition brought about by the recent legal officialization of third-gender markers.

Although there is an evident 'recognition gap' (Lamont, 2018) caused by the inability of institutions to provide sufficient recognition of gender identity, the gap argument is not sufficient to understand why misrecognition is systematically perpetuated, even when increased dynamics of institutional recognition are taking place (Aboim, 2020). My central argument asserts that the politics of recognition is complicit with misrecognition for two main reasons. Firstly, because models of recognition tend to equalize all the interactions and all the fields of social life. Drawing on Axel Honneth's notion of spheres of recognition, I argue that inasmuch as different forms of recognition (legal, moral, affective) are governed by different normative principles and belong to different gender regimes, the dynamics of recognition work in ways that produce misrecognition. Secondly, because legal and institutional recognition tends to reify individual identity. In conversation with Nancy Fraser's critique of the identity model of recognition, I contend that the identification of gender minorities through a specific gender marker is shown to generate misrecognition. The problem is that the identity recognition model tends to impose a norm rather than recognizing diversity, thereby compromising the politics of respectful difference initially sought after. Therefore, paradoxically, gender identity categories can-through a process of reificationblock the entitlement to affirm one's self-determined gender identity.

Recent debates and legal solutions for the officialization and institutionalization of third-gender markers illustrate the paradoxical dynamics of recognition. If state regulation of gender difference garnered critical debate, less attention has been given to the value, whether instrumental or symbolic, of third-gender categories for gender-nonconforming individuals, especially outside Europe and North America. Aiming to narrow this gap, my argument is empirically illustrated by a qualitative study that combined document analysis of legal and institutional developments with in-depth interviews with trans and gender-nonconforming individuals. By examining the case of Nepal and the narratives of Nepali trans migrants in Europe, I seek to demonstrate that the identity model of recognition produces practices of misrecognition. Although the Nepali case is singled out, findings are interpreted in comparison with developments in Asia and South America and carry important lessons to the European context.

\section{Paradoxes of Recognition}

In the current battles for transgender recognition, heated arguments have fuelled the divide between supporters of state-endorsed third-gender markers and the abolition of public interference on the private experience 
of gender. The debate brought the problem of recognition to the forefront of the discussion, with some arguing in favour and others against political and institutional recognition (Halberstam, 2018). Therefore, although the critical analysis of recognition is not new, a more productive approach implies addressing the paradoxical character of recognition. In order to understand how misrecognition is implicated in every act of recognition, I advance two central arguments for explaining the paradoxes of recognition. Firstly, each sphere of recognition is different and works according to its own particular norms and gender regimes. Secondly, the identity model underpinning present-day recognition politics forcefully categorizes people in ways that constrain their freedom and produce reification (Fraser, 2000).

\subsection{The Spheres of Recognition: Moral and Legal Disjunctions}

Current formulations of minority political agendas are greatly indebted to Charles Taylor's theorization of recognition. In a nutshell, Taylor demonstrated that the universal entitlement to equality is reconcilable with the right to difference and that the specific importance of recognition lies in its relationship to identity, which he defined as "a person's understanding of who they are, of their fundamental characteristics as a human being" (Taylor \& Gutmann, 1994, p. 25). The politics of transgender recognition has not been an exception and also sought inspiration in Taylor's formulation (Juang, 2013; Taylor, 1992). After all, the struggle to freely self-determine one's own gender identity is anchored in a politics of difference in which the uniqueness of each individual must be recognized (Hines, 2013).

Approaches to recognition awarded little attention to Axel Honneth's landmark contribution (Honneth, $1995,2008)$, when, in fact, Honneth's multidimensional theorization of different spheres of recognition is extremely helpful to understand the shortcomings of recognition politics (Aboim, 2020). More than a recognition gap that institutions would be able to fulfil, with the right amount of investment, the failures of recognition might not be so easily fixed and the reasons behind it signal one central problem: The fact that the dynamics of recognition tend to equalize very different forms of recognition. However, given that each social sphere is governed by a different principle of recognition and belongs to a different regime of power (gender regime in the case), this equalization is problematic. For this reason, Honneth's theorization helps us understand the problem.

In a recent interview, Honneth claimed that "the focus on an analysis of society has turned the three [love, rights and solidarity] original forms of recognition into five" (Willig \& Honneth, 2012, p. 148). In the aftermath of the theoretical dialogue with Nancy Fraser, Honneth (2014) distinguished between legal and moral recognition, and three institutional spheres of practice: personal relationships, mutual satisfaction of needs, and communicative will-formation. For my current purpose, I will hold on to the distinction between legal and moral social spheres of recognition, which Honneth respectively equates with the state-of-law and institutionalized individualism, that is, organized self-realization.

Moral recognition implicates the right to selfdetermination and self-esteem achieved through intersubjective mutual recognition. For Honneth (2014), subjects are constituted by acts of recognition from which they derive self-worth and the very possibility of existence. Hence, the primary form of recognition is necessarily moral. Any act of non-recognition or misrecognition generates, at the very least, vulnerability, if not the deprivation of agency. As Honneth explains, "human beings are vulnerable in the specific manner we call 'moral' because they owe their identity to the construction of a practical self-relation that is, from the beginning, dependent upon the help and affirmation of other human beings" (Honneth, 1995, p. 51). However, moral recognition (ultimately, self-determination) is not independent of the self-respect achieved through rights within the legal sphere. The possibility of identity realization depends on both moral and legal principles, which can only be achieved intersubjectively. Moral recognition would ultimately depend on being granted respect by the state-of-law. Equal legal standing would imply rights and, more importantly, the moral value of difference and respect. The problem is that moral entitlement to identity and difference and legal recognition enforced by the state-of-law are often strange bedfellows. In the case of trans recognition, recent research (e.g., Scherpe, 2017) proved that, in most cases, there is an evident incongruity between the moral and the legal or, in other words, the subjective dimension of the self and the regulatory dimension where institutional practices of mutual recognition take effect (e.g., Fraser, 2000).

Indisputably, as Nancy Fraser $(2000$, p. 280$)$ contended: "Misrecognition is an institutional social relation not a psychological state." Indeed, institutional regulations often collide with personal feelings of gender authenticity. Furthermore, the fact that each sphere of recognition belongs to different regimes within the gender order-what Connell defines as "the current state of play in the macro-politics of gender" (Connell, 1987, p. 20)-reinforces the disjunction between the different social spheres. For Connell, a gender regime refers to the state of play of gender relations in a given institution. For example, state regulation, and symbolic relations constitute different regimes within a system of hierarchically formed positions (Connell, 1987).

By suggesting that (1) moral entitlement to difference does not always accord with group forged identity claims, and that (2) norms and institutional regulations governing different spheres of recognition are often irreconcilable, I content that recognition is paradoxical. Such paradoxes necessarily weight upon political strategies of recognition. 


\subsection{Identity Recognition and the Limits of Categories}

Conceptualizing recognition as necessarily fragmented and subjugated to the often-irreconcilable norms and dynamics of different spheres of social life helps us to make sense of a second argument. That is the problem of identity. As Nancy Fraser already argued, "by equating the politics of recognition with identity politics, it encourages both the reification of group identities and the displacement of redistribution" (Fraser, 2000, p. 110). Similarly, McNay contends that any quest for the authenticity of the self produces essentialist accounts of identity (McNay, 2008, pp. 64-66), that is, the struggle for being recognized as one's own self tends to produce reification. Taylor had responded to the critique of unintended identitarianism by defending a politics of difference premised upon what he saw as "a universal respect for the human capacity to form one's identity" (Taylor \& Gutmann, 1994, p. 42). The reification of identity categories and the ensuing dismissal of difference in the strategies of identity politics remained problematic.

Indeed, the emphasis on recognition, as the result of an intersubjective experience transferred from the moral to the legal sphere, has been the cornerstone of identity politics. However, although identity politics is often paralleled with a 'politics of difference' (Massoumi, 2015), the moral right to difference has barely been mirrored in legal developments. As many advert (see Juang, 2013), most frequently, one particular identity that belongs to just a few might become predominant and is extended to the whole group. Diversity is then swept under the rug. Even if for long identitarian sameness has been harshly criticized (Young, 1990, p. 159), the tension between a common political identity and the respect for difference seems irresolvable. Ideally, the identity of a person ought to be the basis of politics and justice. Nevertheless, this is barely the reality. This paradoxical dynamic occurs whether misrecognition results from the absence of appreciation by others of one's identity (Taylor \& Gutmann, 1994, p. 25) or, as Honneth adverts, from humiliation and disrespect enacted by others, institutions and the state (Fraser \& Honneth, 2003, p. 134).

In a perfect model of recognition, individuals would be given the capacity to decide who they are and act accordingly to realize their identity in and across different social spheres. However, a category of identity tends to generate a norm that includes certain traits and excludes others. If this category intends to recognize a specific identity, then it might block individuals' subjective understandings of who they are or want to become, while forcing people to articulate an exterior identity that might be forced upon them. That is to say, an exterior categorical identity that serves the interest of the state and enables renewed forms of classification to emerge. This peril has been a cornerstone in the poststructuralist deconstructionist critical contribution. As Butler alerted, following Foucault's insights, identity categories "are never merely descriptive, but always normative, and as such, exclu- sionary" (Butler, 1997, p. 16). In this sense, gender markers are more than words or semantic propositions. Like any other categories, they enable and disable, creating challenges to be considered in the struggle for trans recognition that must necessarily be measured against the empirical reality of practice.

Largely, the problem rests with the dubious character of gender categories, which seem both reductionist and indispensable, not only for reasons of intelligibility but also for the pursuit of justice through the politics of identity. But whenever one deconstructs, the most probable outcome is the multiplication of the categorical inroads to diversity. From the start, the process of breaking falsely constructed homogeneities is tense and unfinished. Already a long time ago, Ken Plummer had resumed this difficulty quite neatly $(1981$, p. 29):

The root issue is to grasp the way in which the world is simultaneously necessarily contingent upon orderly categories through which we may grasp it and how simultaneously such categories inevitably restrict our experiences and serve material forces of domination and control. We cannot live without them but living with them is a horror! Categorization is paradoxical: It aids and destroys.

Categorization, even in the form of a gender marker, might be necessary, but it is also dangerous. One major risk would be obliterating some identities and claims by imposing a hierarchy of legitimacy, which normatively separates the insiders from the outsiders. Then, instead of a form of tactical strategic essentialism, to borrow Spivak's (1985) landmark concept, the likelihood of imposing a particular, and necessarily narrow, discourse on the right form of trans identity would be considerable. One important consequence of any narrow interpretation of trans identities would be the erasure or distortion of some forms of gender expression. For instance, as Viviane Namaste (2005) pointed out, the category transsexual is being gradually erased from public arenas. As Dietz (2018) points out, the 'wrong body' narrative still shapes legal provisions and limits the effect of identity self-declaration for many trans and gendernonconforming individuals. Conversely, the visibility of transgender individuals in and from non-Western societies feeds the imaginaries of exotic third-gender groups (Towle \& Morgan, 2006), thereby reproducing the divide between the 'west and the rest'. Furthermore, the complicity between third-gender laws and the protection of patriarchy often reproduces patterns of marginalization that set gender-nonconforming individuals apart as non-normative and pathological, as demonstrated by Nisar (2018) for the case of Pakistan. For that reason, adopting the legal third-gender can contribute to social marginalization, reinforcement of stereotypes and worse economic conditions. All erasures and distortions promote then the de-ontologization of subjects, sacrificing the entitlement to difference for the sake of a collective 
identity, which too often only very partially produces a positive recognition of difference.

Revising recognition, and, above all, for comprehending the paradoxes of the model of identity recognition, is thus vital for rethinking the possibilities of realization of a gender identity politics. The fact is that institutionalized (neo-liberal) individualism is difficult to reconcile with identity claims. On the one hand, neoliberal forms of governance promote the value of individualism against collective organization (or resistance). On the other hand, however, the normalization of identities to fit the patterns of mainstream culture is also encouraged (e.g., Richardson, 2017). Recognition comes with an effective price, considering that increased visibility might not correspond to increased respect for difference (Gossett, Stanley, \& Burton, 2017).

Although gender identity is vital for many individuals (e.g., Butler \& Williams, 2014), political models of identity recognition remain problematic. The multiple subjectivities, expressions and performances of gender difference do not necessarily form a common identity in the strong sense of the term. Agreeing with Nancy Fraser (2001), the common element would be the fact that trans and gender-nonconforming individuals share the same status of subalternity. The main difficulty is that the identity model of recognition tends to produce misrecognition, a disjunction between different social spheres and the reification of normative identities.

In the section that follows, I briefly contextualize the expansion of third-gender markers and how activist claims have been reinterpreted in legal developments and institutional policies.

\section{Legal Thirdness: Officialising Gender beyond the Binary}

In recent years, international law gradually increased the regulation of gender diversity (Plummer, 2015). Pressure from trans rights activists and organizations has undoubtedly triggered the change produced by state agencies in gender classification systems (Waites, 2009). Back in 2007, the Yogyakarta Principles had already established that recognition before the law of each person's self-defined gender identity was a fundamental human right. A decade later, Principle 31 of The Yogyakarta Principles Plus 10 (2017) recommended that sex and gender markers should only be legally registered for a legitimate purpose. More: Sex and gender markers should accommodate multiple options through legal provisions and institutional mechanisms that "recognise and affirm each person's self-defined gender identity" (The Yogyakarta Principles Plus 10, 2017, p. 9). Ideally, however, Principle 31 established that the right to legal recognition should not require any reference to or disclosure of "sex, gender, sexual orientation, gender identity, gender expression or sex characteristics." In 2018, Transgender Europe endorsed Principle 31, "calling for the full abolition of gender markers on official iden- tity documents." Activists' commitment to transgender recognition is not entirely opposed to gender abolitionist claims. After all, multiple gender marker options must eventually be eliminated from identification documents and bureaucratic procedures. The groundswell of trans rights refuelled the hopes of reconstructing gender classification schemes afresh (McQueen, 2015).

However, rather than moving towards the full or, at least, extensive legal elimination of gender markers, lawmakers responded by expanding the binary classification through the addition of a third-gender category (even if concomitantly eliminating sex or gender from some documents and procedures). Until now, a small but growing number of countries followed this route.

Although gender identity laws are today in place in more than forty countries, third-gender markers (Holzer, 2018) are available in a smaller number of countries and regions. Whether more or less neutral, third-gender markers are being applied in different ways, even if always within a ternary system of classification ( $M$ and $F$ plus $X$, Diverse, Other, etc.). The new gender marker might cover only intersex people, like in the case of Germany. The changes recently implemented in Germany motivated reactions of disappointment (Transgender Europe, 2019), inasmuch as the majority of non-binary people remain excluded from third-gender markers. In fact, following the decision of the Federal Constitutional Court of Germany in 2017, the German parliament committed to either abolishing the requirement to register gender at birth or creating additional gender options. However, the third-gender option (divers) announced in August 2018 and made official in January 2019 is available only to people with intersex variance.

Conversely, a second model might include all people who identify with a non-binary gender, but normally with restrictions. In Australia, which pioneered the expansion of the gender binary classification system in 2002, the application of the legal right to a non-binary identity is limited insofar as the majority of government services continues to offer only $\mathrm{M}$ and $\mathrm{F}$ gender marker options and a medical certificate is required (Australian Government, 2015). Systemic discrimination explains, therefore, the low uptake for gender ' $X$ ' passports, which amounts to just 110, since they became available in 2002 (Pollock, 2018). Similarly, in Malta, only one gender ' $X$ ' passport was issued since September 2017, when the third-gender marker ' $X$ ' was legally introduced. In some cases, like New York among many other examples, territorial gaps in legislation are problematic. Since 2019 , X gender markers are available in New York City, whereas the State of New York does not allow for non-binary classifications. In some cases, the expansion of gender markers might be exceptional and prospective. Countries, like France, Ireland or The Netherlands, have already issued genderneutral passports even if legal provisions are yet under debate.

In countries with indigenous traditions of a thirdgender category (that is, gender identities that do not fall 
exclusively in man/male or woman/female categories; for an overview, see Darwin, 2017; Nanda, 2000), like India (2009), Pakistan, (2009) or Nepal (2007), official recognition of those who are neither man nor woman might foster the mainstreaming of an institutionalized 'disability' (Hossain, 2017, p. 9). In effect, activists' contestation of third-gender laws in places as different as Australia or Germany and India or Nepal-which have been frequently mediatized as progressive (e.g., Young, 2016)-emphasized that 'third classifications' (whether explicitly Other or even coded X or Indeterminate) might contribute to strengthening the gender binary (Council of Europe Commissioner for Human Rights, 2015). In truth, the third-gender recognition model might confer legal protection and enable affirmative action while concurrently sanctioning a limited recognition of gender diversity that faces the perils of stereotypization. One exemplary case is Nepal.

In 2007, the Supreme Court of Nepal delivered a breakthrough pronouncement (Bochenek \& Knight, 2012 , p. 2). Ruling out all medical requirements, the court's rule responded to claims of the Blue Diamond Society, a Nepali LGBTI rights organization led by Sunil Babu Pant and established a third-gender category (Other) "under which female third-gender, male thirdgender and intersexual are grouped, as per the concerned person's self-feeling" (Sunil Babu Pant and Others v. Nepal Government and Others, 2008, p. 281). Alongside the conflation of sex, gender identity and sexual orientation in a single ' $O$ ' category, de facto recognition is extremely problematic. As Chhetri (2017, p. 108) notes, "in Nepal, third-gender persons are visible in human right documents, given equal rights in legal spheres but at the same time they are ignored and neglected in implementations of those rights." A 2013 survey (Knight et al., 2015) showed that very few individuals had access to the official third-gender marker. Only five respondents had successfully changed their citizenship documents.

In this battlefield, distrust from any form of stateendorsed regulation is reasonable, with the solution residing for many activists and scholars in the undoing of all gender classifications (Stryker, 2019), as the only way to disassemble a society in which hospitals, prisons or toilettes and bureaucratic forms are gendersegregated (Davis, 2017). Notwithstanding, the absence of third-gender official regulations might increase the harmful effect of non-recognition and misrecognition. As a double-edged sword, increased visibility has led to an escalating of violence against trans and gender non-conforming people (Gossett et al., 2017). According to the Trans Murder Monitoring project (Transgender Europe \& Balzer, 2020), between January 2008 and September 2019, 3,314 trans and gender-diverse were reported worldwide to have been killed.

In yet another group of countries, the governance of gender-nonconforming populations has not escaped state power and forms of unofficial or semi-official regulation were established. One such example is Brazil.
While violence against gender-nonconforming individuals is endemic (in Brazil alone, 1,368 trans people were murdered since 2008), travestis are separated from other inmates in Brazilian prisons (Ferreira, 2015). Thailand is another exemplary case. Although political efforts to recognize a third-gender category are already visible, transgender people (kathoeys) are normally exempted from army duty or allocated separated dorms or toilettes (United Nations Development Programme, 2018). In sum, whether states opt for the official creation of gender categories beyond the binary or semi-official protection strategies, the governance of gender-nonconforming individuals implicates the state and forms of institutional management. Whether further legal recognition framed under a human rights paradigm will be able to award individuals truly inclusive gender citizenship remains a problem (Baisely, 2016).

Most often, regulation comes with a price, as Halberstam (2018, p. 47) alerted. A model of the official trans person, most often ignoring all forms of intersectional disadvantage, materializes swiftly to the detriment of plural claims and identities (Spade, 2013). Furthermore, as argued by McQueen (2015), recognition, and legal recognition in particular, can produce both enabling and disabling effects. While even the most encompassing models of gender identity suffer from a recognition gap that institutional policies are unable to close up, misrecognition is a more structural and profound consequence. Recognition tends to produce misrecognition.

The analysis of the effects of third-gender categories for gender-nonconforming people might help us shed further light on the dilemmas of trans politics. In the coming section, we will learn more about the production of misrecognition in legal and social practice.

\section{Third-Gender Markers: Misrecognition in Practice}

The production of a given gender category, as in any other identity formation, often results from and leads to processes of simplification and reification. Third-gender markers are particularly relevant to my analysis. For that reason, in this section, I will focus on the potential effects of third-gender legal solutions for gendernonconforming individuals by examining how normative prescriptions block individuals' realization of their gender identity. Two difficulties become evident. Firstly, how legal and institutional categories of gender become embedded in social life and affect practices of mutual recognition in other spheres, and, secondly, how certain formulations of identity crystallize and become reified.

My analysis draws on a qualitative study that combined the examination of legal and institutional documents and in-depth interviews with trans and gendernonconforming people in five European countries over the course of the past three years: Portugal, France, the United Kingdom, The Netherlands and Sweden. In total, 160 in-depth interviews were carried out with individuals with different gender identifications and var- 
ious national origins. More than 40 percent of participants (69) self-defined beyond the gender binary, whether as non-binary, genderqueer, bigender, agender, genderfluid or as crossdresser, travesti, two-spirit, kathoey, third-gender, among other identifications. Onethird (53) of the participants are migrants, the majority of which from South America (21) and Asia (14). Of these, 15 individuals came from Brazil, 7 from Nepal and 4 from Thailand. In all the remaining cases, only one individual came from each country.

Nepal, Brazil and Thailand share what Nanda (2000) called an indigenous tradition of the third-gender and all are stage to trans and gender-nonconforming activist movements. However, while both Brazil and Thailand implemented institutional policies to govern gender difference in specific settings (such as prisons or dorms, as aforementioned), only Nepal put into effect a legal third-gender solution. Therefore, the case of Nepalexamined from a comparative perspective-enabled me to further explore the contradictions of third-gender legal solutions. Aside from the opportunity of interviewing Nepali trans-migrants in Portugal and the United Kingdom, which offered precious insights into individuals' views on third-gender legal options, two reasons underpinned this option. Firstly, alongside a number of South Asian countries, Nepal was a legal frontrunner in matters of third-gender legislation, and while we often centre our attention in western developments many pioneering changes are taking place in other parts of the globe. Secondly, although Nepal represents a very specific model of legal recognition, where all trans and gender-nonconforming individuals must fit the Other gender marker option, the more detailed analysis of how Nepali participants were (or not) affected by the law highlights vital problems of official gender categories. The narratives of Brazilian and Thai participants will serve as a benchmark.

In both the United Kingdom and Portugal (where the interviews took place), trans and gender-nonconforming British and Portuguese nationals are divided between solutions that fully, or at least partially, abolish gender markers and solutions that enforce a ternary classification system, with a neutral form of gender added to the $\mathrm{F}$ and $\mathrm{M}$ boxes. The findings closely follow those of other studies (e.g. Rodrigues, 2019; Valentine, 2016). Among the Nepali interviewees, only one participant identified as third-gender. All others preferred terms such as trans, transgender or transsexual. None had changed their legal gender. In comparison, nine Brazilian and two Thai participants identified as neither man nor woman, whether as travesti, kathoey or non-binary. Participants were recruited by various means (personal contacts, participation in events, networks associated with trans rights organizations) and a snow-ball method was used. All participants were provided with detailed information about the aims and procedures of the study and were cognizant that their participation was voluntary and could be withdrawn at any moment. The terms of confiden- tiality and use of the information gathered in the interview were outlined. It was made clear that results would be reported in such a way that no individual would be identifiable.

Let us examine the limitations of legal recognition to illustrate how the disjunction between moral and legal spheres and the reification of identity.

The Nepali one-suit-all third-gender category might represent a move towards progress in matters of state recognition, but the ternary system of gender classification is not able to include everyone. Firstly, because the gender marker Others, while representing a historical and cultural notion of the existing third-gender, might, as a result, conflate too many sub-categories. The 2013 survey demonstrated that respondents identified with multiple identity terms related to both their gender identity and sexual orientation. While 43.9 percent of the respondents self-identified as third-gender (using terms such as 'Meti,' 'Kothi,' 'Hijara,' 'Third-gender,' 'Transgender'), more than half preferred other terms, from gay and lesbian to men and women to trans and transgender. The legal Other category, though interpreted as enunciating the third-gender, does not translate the multiplicity and complexity of self-identification. Rather, it produces a sort of a legal umbrella category that might distort individuals' sense of who they are and what their gender is.

Indeed, for some, the third-gender option might not be a solution. These are the cases of Alisha (35, transgender woman) and Devna (29, transgender woman). Both women migrated from Nepal and live in Lisbon at present. As Alisha explains:

I feel that I don't exist whether at home or here in Europe. I don't want to be the hijara but I'm no woman either, they don't let me. So who am I supposed to be? I look mostly female, and I feel female, but my passport is male, so it's a nightmare. I cannot change my legal sex to be a woman and I don' $\mathrm{t}^{\prime}$ want that other thing. I'm not Other! I'm just tired of being so persecuted. There should be an alternative for people like me....Like not having one face and a different passport, why we need those documents? I don't want anyone to see my identification until I can change that. But I'm meant to be a woman, I'm not like others. It's fine, but it's not me.

If freedom to check the $\mathrm{M}$ or $\mathrm{F}$ gender boxes is restricted, producing what Namaste (2005) termed as the erasure of the transsexual, for those who identify neither as a man nor as a woman, being just Other can be felt like a form of misrecognition. Maaya (26, third-gender/non-binary, living in England) explained this feeling quite well:

I never thought I was a woman, I don't think I'm a woman. I never felt like a man either....For many years, I was just a gay boy, a meti, then I thought I might be a third-gender, but never told anyone really. I was afraid of what my family, my boss, my friends would do, it 
was difficult, and so I hide it. I'm still very afraid, but here I went to a support group....They told me it's ok, that I'm non-binary, but I don't know yet. I could be third-gender, after all I'm not a true woman, I don't feel like a man, so I'm in the middle.

Interviewer: Would you like to change your gender in legal documents in your home country?

Maybe, but not now. I don't like that system, what's being other? I know we are just others, not at all respected, not at all considered like who we are. I don't want my documents to say other or third-gender, that's bad. Maybe someday, we will have many genders and respect, and perhaps there is a better name for us. For now, no, not in my country, and not here too. I don't think people understand us, especially when you are a migrant they think the worst.

The excerpt of the conversation with Maaya is revealing of how an identity category can distort one's own sense of gender authenticity. In fact, umbrella gender categories, whether legal or not, might create and feed identities that are unfitting and reifying. Whether specific thirdgender markers are on the table or non-binary recognition is under debate, the systems of gender categorization might produce relevant forms of misrecognition.

While none of the seven Nepali participants had legally changed their gender at the time of the interview, the legal provision transformed the ways they felt others perceived them in their home country. Sabita (33, transgender woman, living in England for a year), who has always felt she was a woman even if she lived as a man for many years, recalls that she felt constrained to conform to a third-gender normativity that was expected of her. Despite the enormous difficulties in accessing the rights granted by the law, trans people like Sabita felt the pressure to become Other in everyday life and institutional settings. As Sabita sombrely narrates:

It's difficult to have a job, a house, just a normal life like everyone else when no one sees who you are, no one cares about who you are. They think they know, and just tell you can't be this or that, they just put you down. I had no job, no nothing. I had to leave my country to become myself.

Interviewer: Did you feel at some point that the legal changes in Nepal were changing things for the better?

Not really, not for me, or many people that I know. Sometimes it was like if you had to fit a role and never aspire to more, like studying to have a degree and becoming someone. I always wanted to be a teacher, but it was impossible. I had to fit and play my part, but never as someone who wants to be successful and happy. Today, I'm a post-op trans woman but no one helped me. Maybe things will change one day.
Similar narratives of institutional misrecognition are common to the vast majority of participants from either Brazil and Thailand or the United Kingdom and Portugal. Many advert that despite activist pressure there is still little space for gender difference. For Nepali migrants, a case which I analysed in greater depth, it became evident that the legal third-gender model limits individuals' moral entitlement to affirm their gender and be publicly recognized for who they are. The official gender classification system produces a fundamental disjunction between the moral and the legal sphere of recognition, which is reinforced the more a particular third-gender category artificially unifies a diverse group of individuals who feel deprived of their own gender identity. Although the Nepali case is exemplary, similar processes of reification (even if differently manifested) are extensive to other geographies across the globe.

The analysis of the Nepali case through the voices of trans and gender-nonconforming Nepali individuals living in Portugal and the United Kingdom permitted us to further understand the workings of third-gender categories in practice (Schilt, 2018). More importantly, it showed how gender classification systems tend to generate misrecognition. Firstly, the Others (or X, Diverse, Indeterminate, for that matter) gender marker seems complicit with the social divide between 'us' and 'them,' that is, between those who fit the norm (the 'gender normals' as pointed out by Garfinkel, 1967) and those who break conventions of gender (the outcasts that need being controlled). As research already demonstrated (Nisar, 2018), third-gender categories do not necessarily challenge the patriarchal gender order. Reservations against third-gender solutions are, therefore, understandable given the limitations posed by this model to the expression of gender diversity.

Secondly, the conflation of a wide range of gender subjectivities and experiences beneath a category that only partially translates historical and cultural notions of gender multiplicity tends to erase gender variance. While a process of reification of the third-gender is in place, the distinction between non-binary western people and nonwestern third-gender individuals is reinforced (Towle \& Morgan, 2006). In other words, the divide between the 'west and the rest' regains power enough to increase misrecognition at the global level.

\section{Conclusion}

By examining the Nepali case against the backdrop of multiple legal and institutional developments aimed at recognizing the right to gender difference, I showed that misrecognition is an accomplice of every act of recognition. Firstly, because recognition takes different forms in different spheres, which renders moral and legal recognition inequivalent. In moral terms, individuals are entitled to gender self-determination, which means being recognized for who they are and being able to self-elect their own gender identity. In legal terms, although third- 
gender categories entail the possibility of moving beyond binary schemes and being awarded rights as a gender nonbinary or nonconforming person, they also impose limits to the definition of gender. Secondly, following Nancy Fraser, because institutional gender markers tend to reify individual identity. In line with my initial arguments, unable to do justice to moral entitlements, the politics of legal recognition is, in this way, shown to have both enabling and disabling effects. Hence, if transgendering recognition is paramount, a critical approach to the concept, as well as the practices and effects it produces, is fundamental.

While putting gender in a box remains (and will perhaps be) a paradoxical (even if necessarily unavoidable) endeavour, imagining a politics without gender categories seems difficult in current times. Despite all critical insight, reinventing recognition beyond the categorical classification scheme of the identity model remains a humongous political challenge. Nonetheless, when applied to the legal sphere of rights, the identity recognition model inevitably generates misrecognition. From this angle, recognition appears to be intrinsically paradoxical, which creates a difficult challenge. For instance, if gender were officially abolished, gender nonconforming individuals would lack legal existence and state protection against discrimination. If gender were multiplied, individuals would feel their identity distorted and narrowed down. If gender were partially eliminated and partially multiplied, the balance would be difficult. In all the above solutions, to some degree, the right to difference might clash with the model of identity recognition implemented. As such, although recognition is vital and necessary, the acknowledgement of its limitations is fundamental. How can we then move towards a more effective recognition beyond the gender binary?

If the battle between a no-gender utopia and the multiplication of gender categories seems almost unsolvable, one potential way out would imply redressing recognition and shifting from the identity model of recognition to practice. In this way, recognizing shared conditions of subalternity (as in Fraser's status model) could be more promising. The prioritization of shared conditions of oppression could eventually ensure that political umbrella-terms were malleable enough to embrace different identities and claims. In any case, even if 'things are done with words,' to paraphrase the landmark expression of J. L. Austin (1962), emphasizing practice is important. While this solution follows Nancy Fraser's status model very closely, it is important emphasizing that such a practice-based perspective (remembering the prioritization of the ontoformativity of practice for transsexual women by Connell, 2012) does not elude recognition. Rather, it implies considering the dense web of intersecting inequalities: not only between trans subjects and cisgender normativity but also between different trans and gender-nonconforming people across the globe.

\section{Acknowledgments}

This work was supported by funding from the European Research Council under the European Union's Seventh Framework Programme (FP7/2007-2013)/ERC grant agreement n. ${ }^{\circ}$ 615594. The funded project 'TRANSRIGHTS: Gender citizenship and sexual rights in Europe: Transgender lives in transnational perspective' reflects only the views of the author, and the European Union cannot be held responsible for any use which may be made of the information contained therein. I would like to express my gratitude to Mieke Verloo and Anna van der Vleuten, who encouraged my participation in this thematic issue, for their constructive and valuable comments. Finally, I would like to thank all the people who agreed to take part in the TRANSRIGHTS project and shared their life stories, dreams and concerns.

\section{Conflict of Interests}

The author declares no conflict of interests.

\section{References}

Aboim, S. (2020). Fragmented recognition: Gender identity between moral and legal spheres. Social Politics: International Studies in Gender, State \& Society. Advance online publication. https://doi.org/ 10.1093/sp/jxaa011

Austin, J. L. (1962). How to do things with words. Cambridge, MA: Harvard University Press.

Australian Government. (2015). Australian government guidelines on the recognition of sex and gender. Australian Government. Retrieved from https://www.ag.gov.au/rights-and-protections/ publications/australian-government-guidelinesrecognition-sex-and-gender

Baisely, E. (2016). Reaching the tipping point? Emerging international human rights norms pertaining to sexual orientation and gender identity. Human Rights Quarterly, 38(1), 150-151.

Bochenek, M., \& Knight, K. (2012). Establishing a thirdgender category in Nepal: Process and prognosis. Emory International Law Review, 26(1), 11-41.

Butler, J. (1997). The psychic life of power: Theories in subjection. Stanford, CA: Stanford University Press.

Butler, J., \& Williams, C. (2014). Gender performance: The TransAdvocate interviews with Judith Butler. TransAdvocate. Retrieved from https://www.trans advocate.com/gender-performance-the-trans advocate-interviews-judith-butler_n_13652.htm

Chhetri, G. (2017). Perceptions about the "third-gender" in Nepal. Dhaulagiri Journal of Sociology and Anthropology, 11, 96-114.

Clarke, J. A. (2019). They, them and theirs. Harvard Law Review, 132, 894-991.

Connell, R. (1987). Gender and power: Society, the person and sexual politics. Cambridge: Polity. 
Connell, R. (2012). Transsexual women and feminist thought. Signs, 37(4), 857-881.

Council of Europe Commissioner for Human Rights. (2015). Human rights and intersex people. Strasbourg: Council of Europe. Retrieved from https://rm. coe.int/16806da5d4

Darwin, H. (2017). Doing gender beyond the binary: A virtual ethnography. Symbolic Interaction, 40(3), 317-334.

Davis, H. F. (2017). Beyond trans: Does gender matter? New York, NY: New York University Press.

Dembroff, R., \& Wodak, D. (2018). He/she/they/ze. Ergo, 5(14), 371-406.

Dietz, C. (2018). Governing legal embodiment: On the limits of self-declaration. Feminist Legal Studies, 26(2), 185-204.

Dunne, P. (2017). Legal gender recognition in Europe: Sterilisation, diagnosis and medical examination requirements. Journal of Social Welfare and Family Law, 39(4), 497-50

Ferreira, G. G. (2015). Travestis e prisões: Experiência social e mecanismos particulares de encarceramento no Brasil [Trasvestis and prisons: Social experience and particular mechanisms of imprisonment in Brazil]. Curitiba: Multideia.

Fine, M., Torrea, M. E., Frost, D. M., \& Cabana, A. L. (2018). Queer solidarities: New activisms erupting at the intersection of structural precarity and radical misrecognition. Journal of Social and Political Psychology, 6(2), 608-630.

Foucault, M. (1988). Politics, philosophy, culture: Interviews and other writings 1977-1984. London: Routledge.

Fraser, N. (2000). Rethinking recognition. New Left Review, 3, 107-120.

Fraser, N. (2001). Recognition without ethics? Theory, Culture and Society, 18(2/3), 21-42.

Fraser, N., \& Honneth, A. (2003). Redistribution or recognition? London: Verso.

Garfinkel, H. (1967). Studies in ethnomethodology. Malden, MA: Blackwell.

Gossett, R., Stanley, E. A., \& Burton, J. (2017). Trap door: Trans cultural production and the politics of visibility. Cambridge, MA: MIT Press.

Halberstam, J. (2018). Trans: A quick and quirky account of gender variability. Oakland, CA: University of California Press.

Hines, S. (2013). Gender diversity, recognition and citizenship: Towards a politics of difference. Basingstoke: Palgrave MacMillan.

Holzer, L. (2018). Non-binary gender registration models in Europe: Report on third-gender marker or no gender marker options. Brussels: ILGA-Europe.

Honneth, A. (1995). The struggle for recognition: The moral grammar of social conflicts. Cambridge: Polity. Honneth, A. (2008). Reification: A new look at an old idea. Oxford: Oxford University Press.

Honneth, A. (2014). Freedom's right: The social founda- tions of democratic life. New York, NY: Columbia University Press.

Hossain, A. (2017). The paradox of recognition: Hijra, third-gender and sexual rights in Bangladesh. Culture, Health \& Sexuality, 19(12), 1418-1431.

Juang, R. (2013). Transgendering the politics of recognition. In S. Stryker \& S. Whittle (Eds.), The transgender studies reader (pp. 706-719). London: Routledge.

Knight, K. G., Flores, A. R., \& Nezhad, S. J. (2015). Surveying Nepal's third-gender: Development, implementation, and analysis. Transgender Studies Quarterly, 2(1), 101-122.

Lamont, M. (2018). Addressing recognition gaps: Destigmatization and the reduction of inequality. American Sociological Review, 83(3), 419-444.

Markard, N. (2018, February 3). Structure and participation: On the significance of the third option for the equality guarantee. IACL-AIDC Blog. Retrieved from https://blog-iacl-aidc.org/the-third-gender/2018/5/ 28/symposium-on-the-third-option-not-man-notwoman-not-nothing-structure-and-participationon-the-significance-of-the-third-option-for-theequality-guarantee

Massoumi, N. (2015). Muslim women, social movements and the 'war on terror.' London: Palgrave Macmillan.

McNay, L. (2008). Against recognition. Cambridge: Polity.

McQueen, P. (2015). Subjectivity, gender and the struggle for recognition. London: Palgrave Macmillan.

Monro, S. (2005). Gender politics. London: Pluto.

Namaste, V. (2005). Sex change, social change. Toronto: Women's Press.

Nanda, S. (2000). Gender diversity: Crosscultural variations. Long Grove, IL: Waveland Press.

Nisar, M. A. (2018). (Un)becoming a man: Legal consciousness of the third-gender category in Pakistan. Gender \& Society, 32(1), 59-81.

Plummer, K. (1981). The making of the modern heterosexual. London: Hutchinson.

Plummer, K. (2015). Cosmopolitan sexualities: Hope and the humanist imagination. London: Polity.

Pollock, S. (2018, September 21). Low uptake for $X$ passports. Freemantle Herald Interactive. Retrieved from https://heraldonlinejournal.com/2018/09/21/ low-uptake-for-x-passports

Powell, T., Shapiro, S., \& Stein, E. (2016). Transgender rights as human rights. AMA Journal of Ethics, 18(11), 1126-1131.

Richardson, D. (2017). Rethinking sexual citizenship. Sociology, 51(2), 208-224.

Rodrigues, M. O. (2019). Possibilidade de reconhecimento legal do terceiro género em Portugal [Possibility of legal recognition of the third gender in Portugal] (Masters dissertation). New University of Lisbon, Lisbon, Portugal.

Salamon, G. (2010). Assuming a body: Transgender and rhetorics of materiality. New York, NY: Columbia University Press.

Scherpe, J. M. (2017). The legal status of transsexual and 
transgender persons. Mortsel: Intersentia.

Schilt, K. (2018). From object to subject: Theorizing transgender lives in gender and power. In J. W. Messerschmidt, P. Y. Martin, M. A. Messner, \& R. Connell (Eds.), Gender reckonings: New social theory and research (pp. 57-70). New York, NY: New York University Press.

Sky, G. (2018). Fight for trans rights but let go of the 'no gender' utopia. The Conversation. Retrieved from https://theconversation.com/fight-for-trans-rightsbut-let-go-of-the-no-gender-utopia-102844

Spade, D. (2008). Documenting gender. Hastings Law Journal, 59(1), 731-841.

Spade, D. (2013). Intersectional resistance and law reform. Signs, 38(4), 1031-1034.

Spade, D. (2015). Normal life: Administrative violence, critical trans politics, and the limits of law. Durham, NC: Duke University Press.

Spivak, G. C. (1985). Can the subaltern speak? Speculations on widow-sacrifice. Wedge, 7(8), 120-130.

Stryker, S. (2019). Undoing sex classification can provide justice. New York Times. Retrieved from https://www.nytimes.com/roomfordebate/2014/ 10/19/is-checking-the-sex-box-necessary/undoingsex-classification-can-provide-justice

Sunil Babu Pant and Others v. Nepal Government and Others, Writ No. 17 of 2064 BS/2007 (2008).

Taylor, C. (1992). The ethics of authenticity. Harvard, MA: Harvard University Press.

Taylor, C., \& Gutmann, A. (1994). Multiculturalism: Examining the politics of recognition. Princeton, NJ: Princeton University Press.

Towle, E. B., \& Morgan, L. M. (2006). Romancing the transgender native: Rethinking the use of the "Thirdgender" concept. In S. Stryker \& S. Whittle (Eds.), The transgender studies reader (pp. 666-684). New York, NY: Routledge.

Transgender Europe. (2018). Position paper on gender markers. Transgender Europe. Retrieved from https://tgeu.org/tgeu-position-paper-on-gendermarkers

Transgender Europe. (2019). Germany introduces Thirdgender-fails trans people. Transgender Europe. Retrieved from https://tgeu.org/germany-introducesthird-gender-fails-trans-people

Transgender Europe, \& Balzer, C. (2020). Trans murder monitoring. Trans Respect. Retrieved from https:// transrespect.org/en/trans-murder-monitoring

United Nations Development Programme. (2018). Legal gender recognition in Thailand: A legal and policy review. Bangkok: United Nations Development Programme in Thailand.

Valentine, V. (2016). Non-binary people's experiences in the UK. Edinburgh: Scottish Trans Alliance.

Waites, M. (2009). Critique of 'sexual orientation' and 'gender identity' in human rights discourse: Global queer politics beyond the Yogyakarta Principles. Contemporary Politics, 15(1), 137-156.

Willig, R., \& Honneth, A. (2012). Grammatology of modern recognition orders: An interview with Axel Honneth. Distinktion Scandinavian Journal of Social Theory, 13(1), 145-149.

The Yogyakarta Principles Plus 10. (2017). Additional principles and state obligations on the application of international human rights law in relation to sexual orientation, gender identity, gender expression and sex characteristics to complement the Yogyakarta principles. The Yogyakarta Principles. Retrieved from http://yogyakartaprinciples.org/principles-en/yp10

Young, H. (2016, February 12). Trans rights: Meet the face of Nepal's progressive 'third-gender' movement. The Guardian. Retrieved from https://www.theguardian. com/global-development-professionals-network/ 2016/feb/12/trans-rights-meet-the-face-of-nepalsprogressive-third-gender-movement

Young, I. M. (1990). Justice and the politics of difference. Princeton, NJ: Princeton University Press.

\section{About the Author}

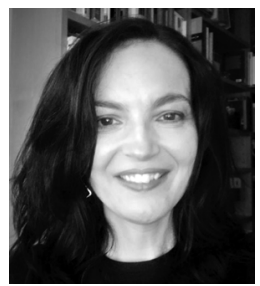

Sofia Aboim is a Permanent Research Fellow at the Institute of Social Sciences of the University of Lisbon. Her research interests include gender, feminisms, masculinity studies as well as social theory, justice, inequality and postcolonial studies. She is currently working on book projects about gender, power and justice while developing research on the same topics. She coordinated the project 'TRANSRIGHTS-Gender citizenship and sexual rights in Europe' (Consolidator Grant) financed by the European Research Council (ERC). 